
$\mathrm{MnO}_{2}$ Nanowire Arrays for

SUBJECT AREAS:

BATTERIES

NANOWIRES

Received

22 July 2013

Accepted

2 October 2013

Published

17 October 2013

\section{Correspondence and} requests for materials should be addressed to

H.X. (xiahui@njust. edu.cn) or J.P.X. (chexiej@nus.edu.sg) \title{
High-Performance Supercapacitors
}

Hui Xia ${ }^{1,2}$, Dongdong Zhu ${ }^{1,2}$, Zhentao Luo ${ }^{3}$, Yue Yu ${ }^{3}$, Xiaoqin Shi', Guoliang Yuan' \& Jianping Xie ${ }^{3}$

'School of Materials Science and Engineering, Nanjing University of Science and Technology, Xiaolingwei 200, Nanjing 210094, China, ${ }^{2}$ Herbert Gleiter Institute of Nanoscience, Nanjing University of Science and Technology, Xiaolingwei 200, Nanjing 210094 , China, ${ }^{3}$ Department of Chemical \& Biomolecular Engineering, Faculty of Engineering, National University of Singapore, Singapore, 117576.

Here we proposed a novel architectural design of a ternary $\mathrm{MnO}_{2}$-based electrode - a hierarchical $\mathrm{Co}_{3} \mathrm{O}_{4} @$ $\mathrm{Pt} @ \mathrm{MnO}_{2}$ core-shell-shell structure, where the complemental features of the three key components (a well-defined $\mathrm{Co}_{3} \mathrm{O}_{4}$ nanowire array on the conductive Ti substrate, an ultrathin layer of small $\mathrm{Pt}$ nanoparticles, and a thin layer of $\mathrm{MnO}_{2}$ nanoflakes) are strategically combined into a single entity to synergize and construct a high-performance electrode for supercapacitors. Owing to the high conductivity of the well-defined $\mathrm{Co}_{3} \mathrm{O}_{4}$ nanowire arrays, in which the conductivity was further enhanced by a thin metal $(\mathrm{Pt})$ coating layer, in combination with the large surface area provided by the small $\mathrm{MnO}_{2}$ nanoflakes, the as-fabricated $\mathrm{Co}_{3} \mathrm{O}_{4} @ \mathrm{Pt} @ \mathrm{MnO}_{2}$ nanowire arrays have exhibited high specific capacitances, good rate capability, and excellent cycling stability. The architectural design demonstrated in this study provides a new approach to fabricate high-performance $\mathrm{MnO}_{2}$-based nanowire arrays for constructing next-generation supercapacitors.

ustainable and renewable energy sources, such as hydropower, solar energy, and wind power, in conjunction with flexible energy storage systems, such as rechargeable batteries and supercapacitors, are one of the key solutions to release the heavy burden on the current energy infrastructure and the environment ${ }^{1-6}$. Recently, supercapacitors have emerged as a new class of promising energy storage devices because of their higher power density, faster charge-discharge rate, and longer cycle lifetime than those of rechargeable batteries ${ }^{7,8}$. Supercapacitors can also store more energy than conventional dielectric capacitors ${ }^{9,10}$. The central issues in the development of practical supercapacitors are the selection and fabrication of high-performance electrode materials. Among the emerging electrode materials for supercapacitors, redox-active transition-metal oxides such as $\mathrm{RuO}_{2}, \mathrm{NiO}, \mathrm{Fe}_{2} \mathrm{O}_{3}, \mathrm{SnO}_{2}$ and $\mathrm{MnO}_{2}$, are the most attractive materials due to their high specific capacitances from the fast and reversible redox reactions on the electrode surface ${ }^{11-15}$.

In particular, $\mathrm{MnO}_{2}$ has drawn recent interest as a potential electrode material for supercapacitors because of its high specific capacitance (theoretical value of $\sim 1370 \mathrm{~F} / \mathrm{g}$ ), low cost, natural abundance, and environmental benignity ${ }^{16,17}$. However, the practical use of $\mathrm{MnO}_{2}$ as electrode materials is largely weight-down due to its poor electrical conductivity $\left(10^{-5}-10^{-6} \mathrm{~S} / \mathrm{cm}\right)^{18-20}$, which limits the charge-discharge rate of the supercapacitors; as well as a relatively small surface area of bulk $\mathrm{MnO}_{2}$, which constraints the energy that can be stored in a particular electrode. An effective way to improve the utilization of $\mathrm{MnO}_{2}$ (thus increasing the energy density) is to reduce the $\mathrm{MnO}_{2}$ particles to the nanometer range, in which small particles have a characteristic high surface to volume ratio. For instance, ultrathin $\left(<100 \mathrm{~nm}\right.$ in thickness) films of $\mathrm{MnO}_{2}$ have shown high specific capacitances ${ }^{21,22}$. The major strategy to improve the electrical conductivity of the $\mathrm{MnO}_{2}$ electrodes is to combine conductive materials (e.g., carbon-based materials, metals, and oxides) to $\mathrm{MnO}_{2}$, forming $\mathrm{MnO}_{2}$ composite electrodes with improved conductivities ${ }^{23,24}$. Taken together, new designs of high-performance $\mathrm{MnO}_{2}$-based electrodes must feature with a desired combination of small-sized $\mathrm{MnO}_{2}$ nanoparticles and a good electrical conductivity with the help from the conductive additives ${ }^{25-28}$.

In this context the recent developments on the conductive metal oxide nanowire arrays (NAs, e.g., $\mathrm{SnO}_{2}$ and $\mathrm{Co}_{3} \mathrm{O}_{4}$ ) look very promising ${ }^{22,29}$. Metal oxide NAs can be easily fabricated on the conductive substrates (e.g., Ti foil). The well-defined NAs have good conductivity and can work as current collectors, providing effective pathways for ion and electron transport throughout the entire electrode. Moreover, the three-dimensional 
conductive scaffold could also maximize the loading of thin $\mathrm{MnO}_{2}$ film and increase the area-normalized capacitances. For example, Liu et al. have developed a method to fabricate $\mathrm{Co}_{3} \mathrm{O}_{4} @ \mathrm{MnO}_{2} \mathrm{NAs}$, which showed a good electrochemical performance in an alkali aqueous electrolyte ${ }^{29}$. The authors attributed its good performance to the $\mathrm{MnO}_{2}$ deposited on the $\mathrm{Co}_{3} \mathrm{O}_{4}$ NAs, which can improve the capacitive performance of $\mathrm{Co}_{3} \mathrm{O}_{4} \cdot \mathrm{Co}_{3} \mathrm{O}_{4}$ is a typical electrode material used in the alkali aqueous electrolyte. However, the practical use of the alkali solution as the electrolyte is limited by its corrosive nature to the metal substrate. There is therefore strong interest in developing high-performance $\mathrm{MnO}_{2}$-based electrodes that could be operated in a neutral aqueous electrolyte to fully realize its potential for supercapacitors. In addition, since $\mathrm{Co}_{3} \mathrm{O}_{4}$ is still a semicondutor material, the relatively poor conductivity of the $\mathrm{Co}_{3} \mathrm{O}_{4} @ \mathrm{MnO}_{2}$ NAs may further affect the capacitive performance of $\mathrm{MnO}_{2}$ in the neutral aqueous electrolyte.

Herein we report a facile approach to fabricate a novel hierarchical $\mathrm{Co}_{3} \mathrm{O}_{4} @ \mathrm{Pt} @ \mathrm{MnO}_{2}$ nanostructure. The as-fabricated $\mathrm{Co}_{3} \mathrm{O}_{4} @ \mathrm{Pt} @$ $\mathrm{MnO}_{2} \mathrm{NA}$ electrode showed very high electrochemical performance for supercapacitors operated in a neutral aqueous electrolyte $(1 \mathrm{M}$ $\mathrm{Na}_{2} \mathrm{SO}_{4}$ solution). The key to fabricate the well-defined ternary $\mathrm{Co}_{3} \mathrm{O}_{4} @ \mathrm{Pt} @ \mathrm{MnO}_{2}$ NAs was to introduce an ultrathin layer of Pt nanoparticles on the $\mathrm{Co}_{3} \mathrm{O}_{4}$ nanowire surface, which not only enhanced the conductivity of the NAs, but also induced a perfect coating of small $\mathrm{MnO}_{2}$ nanoflakes on the NAs. The as-fabricated $\mathrm{Co}_{3} \mathrm{O}_{4} @ \mathrm{Pt} @ \mathrm{MnO}_{2}$ electrode showed several desirable electrochemical features for supercapacitors: a high specific capacitance $(497 \mathrm{~F} / \mathrm{g}$ on the basis of $\mathrm{MnO}_{2}$ mass by cyclic voltammetry and $539 \mathrm{~F} / \mathrm{g}$ by galvanostatic charge-discharge at $1 \mathrm{~A} / \mathrm{g}$ ), good rate performance (39.6 Wh/kg at $40 \mathrm{~A} / \mathrm{g}$ ), and excellent cycling performance (no capacity loss over 5000 cycles).

\section{Results}

As illustrated in Figure 1, the fabrication of $\mathrm{Co}_{3} \mathrm{O}_{4} @ \mathrm{Pt} @ \mathrm{MnO}_{2} \mathrm{NAs}$ on the $\mathrm{Ti}$ foil involved three steps. In the first step, $\mathrm{Co}_{3} \mathrm{O}_{4} \mathrm{NAs}$ were grown on the $\mathrm{Ti}$ foil according to published hydrothermal procedures $^{30}$. The second step was the coating of small Pt nanoparticles $(10-20 \mathrm{~nm})$ on the $\mathrm{Co}_{3} \mathrm{O}_{4}$ nanowire surface by using a common sputter-coater. The final step was the deposition of a thin layer of $\mathrm{MnO}_{2}$ on the Pt-coated $\mathrm{Co}_{3} \mathrm{O}_{4}$ NAs via a chemical bath deposition method, forming $\mathrm{Co}_{3} \mathrm{O}_{4} @ \mathrm{Pt} @ \mathrm{MnO}_{2} \mathrm{NAs}$ as the final product.

The successful fabrication of $\mathrm{Co}_{3} \mathrm{O}_{4} @ \mathrm{Pt} @ \mathrm{MnO}_{2} \mathrm{NAs}$ on the Ti foil was first confirmed by powder X-ray diffraction (XRD). As shown in Figure 2 (black line), the diffraction patterns of the bare $\mathrm{Co}_{3} \mathrm{O}_{4} \mathrm{NAs}$ in the $2 \theta$ range of $10-80^{\circ}$ could be indexed to the cubic phase $\mathrm{Co}_{3} \mathrm{O}_{4}$ (JCPDS Card No. 42-1467). The three peaks marked by "\#" belong to the Ti substrate. In contrast, besides the peaks from $\mathrm{Co}_{3} \mathrm{O}_{4}$ and $\mathrm{Ti}$,

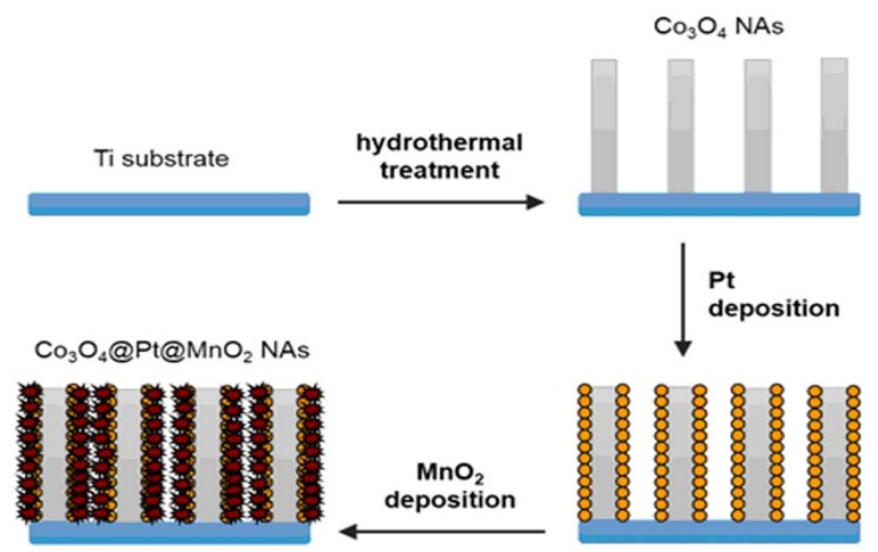

Figure $1 \mid$ Schematic illustration of the fabrication process of the $\mathrm{Co}_{3} \mathrm{O}_{4} @$ $\mathrm{Pt} @ \mathrm{MnO}_{2} \mathrm{NAs}$.

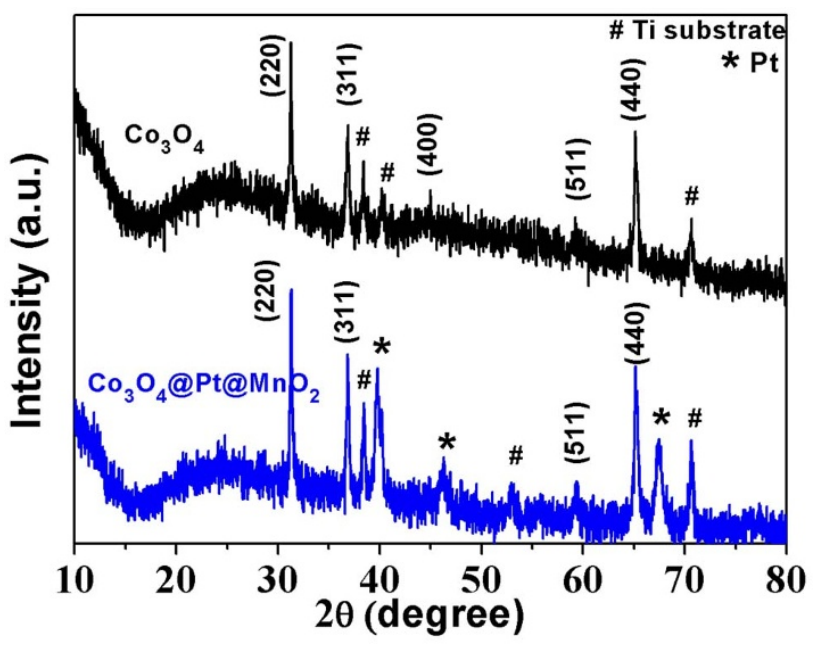

Figure $2 \mid$ XRD patterns of the $\mathrm{Co}_{3} \mathrm{O}_{4}$ NAs (black line) and $\mathrm{Co}_{3} \mathrm{O}_{4} @ \mathrm{Pt} @$ $\mathrm{MnO}_{2}$ NAs (blue line).

the XRD patterns of the $\mathrm{Co}_{3} \mathrm{O}_{4} @ \mathrm{Pt} @ \mathrm{MnO}_{2} \mathrm{NAs}$ (blue line) showed three additional diffraction peaks (marked by "*") in the $2 \theta$ range of $10-80^{\circ}$, indexable to the (111), (200), and (220) reflections of facecentered cubic (fcc) Pt (JCPDS, Card No. 4-0802). This data supports the successful coating of $\mathrm{Pt}$ nanoparticles on the $\mathrm{Co}_{3} \mathrm{O}_{4}$ NAs. It should be mentioned that no peaks pertaining to $\mathrm{MnO}_{2}$ crystals were observed in the XRD patterns of the $\mathrm{Co}_{3} \mathrm{O}_{4} @ \mathrm{Pt} @ \mathrm{MnO}_{2} \mathrm{NAs}$, which suggests that the deposited $\mathrm{MnO}_{2}$ thin film on the NA surface is most likely amorphous or poorly crystallized, similar to two earlier observations in the $\mathrm{MnO}_{2}$ deposition ${ }^{31,32}$.

$\mathrm{X}$-ray photoelectron spectroscopy (XPS) was then used to confirm the chemical composition and metal oxidation states of the $\mathrm{Co}_{3} \mathrm{O}_{4} @$ Pt@MnO $\mathrm{Mn}_{2}$ NAs. Six elements (Mn, Co, Ti, Pt, O, and C) were identified from the full-survey-scan spectrum of the NAs (Figure S1). Panels A, B, C, and D of Figure 3 show the Mn 2p, Co 2p, O 1s, and Pt 4f core level spectra of the $\mathrm{Co}_{3} \mathrm{O}_{4} @ \mathrm{Pt} @ \mathrm{MnO}_{2} \mathrm{NAs}$, respectively. Two distinct peaks at binding energies of 642.1 and $653.5 \mathrm{eV}$ with the spin-orbital splitting of $11.4 \mathrm{eV}$ were observed in the Mn 2p core level spectrum (Figure 3a), which correspond well to the Mn $2 \mathrm{p}_{3 / 2}$ and $\mathrm{Mn} 2 \mathrm{p}_{1 / 2}$ in $\mathrm{MnO}_{2}$, respectively ${ }^{33,34}$. Deconvolution of complex Co $2 \mathrm{p}$ spectrum (Figure $3 \mathrm{~b}$ ) suggests the presence of two chemically distinct species: $\mathrm{Co}^{2+}$ and $\mathrm{Co}^{3+}$. In particular, two distinct peaks at 779.9 and $795.1 \mathrm{eV}$ could be assigned to $2 \mathrm{p}_{3 / 2}$ and $2 \mathrm{p}_{1 / 2}$ of $\mathrm{Co}^{2+}$, respectively; whereas two small peaks at 788.9 and $803.5 \mathrm{eV}$ could be attributed to $2 \mathrm{p}_{3 / 2}$ and $2 \mathrm{p}_{1 / 2}$ of $\mathrm{Co}^{3+}$, respectively. This data provide direct evidence for the presence of $\mathrm{Co}_{3} \mathrm{O}_{4}$ phase in the asfabricated $\mathrm{NAs}^{35-37}$. The $\mathrm{O}$ 1s core level spectrum (Figure 3c) had three distinct components. Besides the $\mathrm{O} 1 \mathrm{~s}$ peaks at 531 and $532.8 \mathrm{eV}$ due to oxygen atoms in the hydroxyl groups and absorbed water ${ }^{38,39}$, respectively, the strong peak at $529.6 \mathrm{eV}$ could be assigned to oxygen atoms in the oxides of $\mathrm{MnO}_{2}$ and $\mathrm{Co}_{3} \mathrm{O}_{4}$. The $\mathrm{Pt} 4 \mathrm{f}$ core level spectrum (Figure 3d) showed two distinct peaks at 70.9 and $74.3 \mathrm{eV}$, which could be attributed to $\mathrm{Pt} 4 \mathrm{f}_{7 / 2}$ and $\mathrm{Pt} 4 \mathrm{f}_{5 / 2}$, respectively, confirming the presence of metallic Pt in the as-fabricated $\mathrm{NAs}^{40}$.

Scanning electron microscopy (SEM) was used to examine the structure of the bare $\mathrm{Co}_{3} \mathrm{O}_{4} \mathrm{NAs}$, and the as-fabricated $\mathrm{Co}_{3} \mathrm{O}_{4} @ \mathrm{Pt}$ and $\mathrm{Co}_{3} \mathrm{O}_{4} @ \mathrm{Pt} @ \mathrm{MnO}_{2} \mathrm{NAs}$. Freestanding and well-aligned $\mathrm{Co}_{3} \mathrm{O}_{4}$ nanowires on the Ti substrate were observed for the bare $\mathrm{Co}_{3} \mathrm{O}_{4} \mathrm{NAs}$, as shown in Figure 4a. The nanowires had a uniform diameter of $\sim 100 \mathrm{~nm}$ (Figure 4b). After the Pt coating (forming $\mathrm{Co}_{3} \mathrm{O}_{4} @ \mathrm{Pt}$ NAs), the diameter of the nanowires did not change much (Figure $4 \mathrm{c}$ and $4 \mathrm{~d}$ ). However, a rough surface of the $\mathrm{Co}_{3} \mathrm{O}_{4} @ \mathrm{Pt}$ nanowires can be seen in the SEM images (Figure $4 c$ and $3 d$ ) as small Pt nanoparticles covered on the nanowire surface. Further deposition 

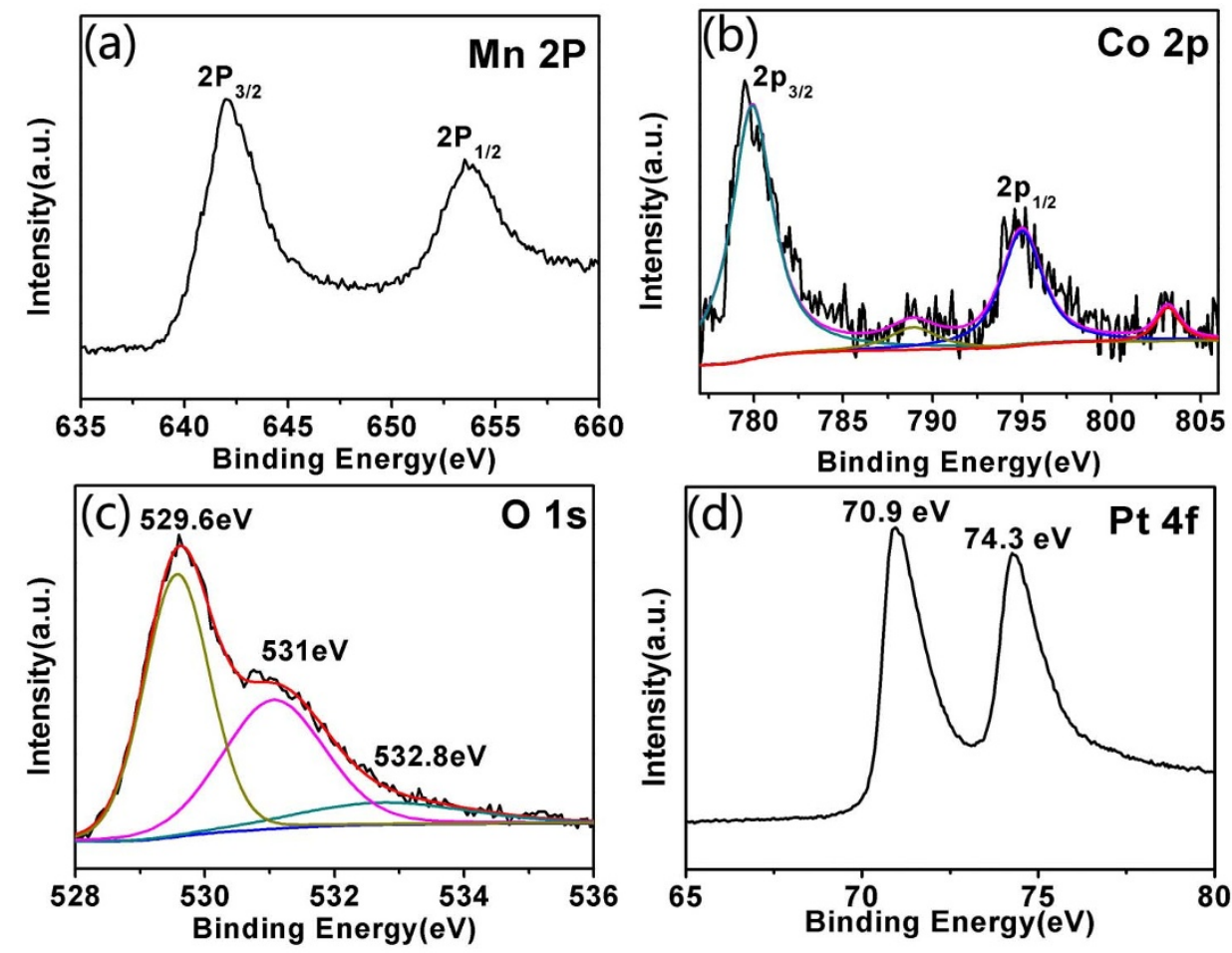

Figure 3 XPS Mn 2p (a), Co 2p (b), O 1s (c), and Pt 4f (d) core-level spectra of the as-fabricated $\mathrm{Co}_{3} \mathrm{O}_{4} @ \mathrm{Pt}_{\mathrm{N}} @ \mathrm{MnO}_{2} \mathrm{NAs}$

of $\mathrm{MnO}_{2}$ on the surface of $\mathrm{Co}_{3} \mathrm{O}_{4} @ \mathrm{Pt} \mathrm{NAs}$ formed $\mathrm{Co}_{3} \mathrm{O}_{4} @ \mathrm{Pt} @$ $\mathrm{MnO}_{2} \mathrm{NAs}$ (Figure 4e), and the diameter of the nanowires increased to $\sim 200 \mathrm{~nm}$ (Figure $4 \mathrm{f}$ ). In addition, a thin layer of $\mathrm{MnO}_{2}$ consisting of small nanoflakes can be seen in the SEM image (Figure $4 \mathrm{f}$ ). It is worth mentioning that the loading amount of $\mathrm{MnO}_{2}$ or the thickness of the thin layer of $\mathrm{MnO}_{2}$ on the $\mathrm{Co}_{3} \mathrm{O}_{4} @ \mathrm{Pt} @ \mathrm{MnO}_{2} \mathrm{NAs}$ can be

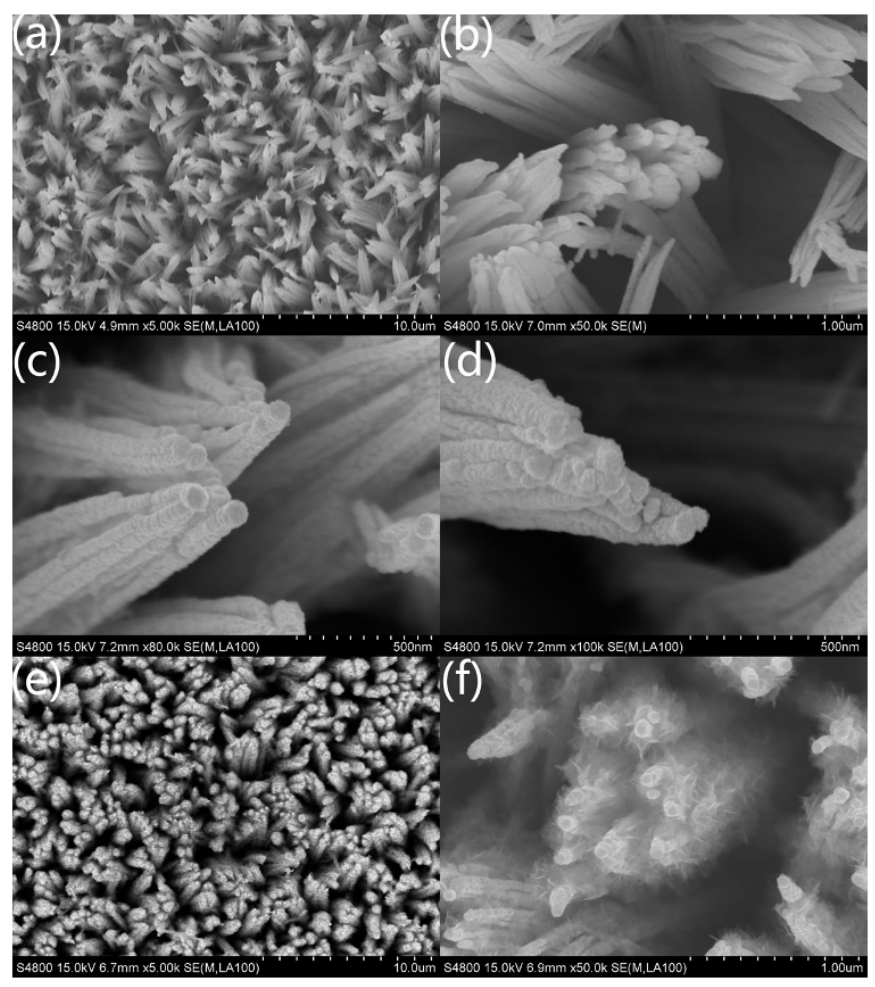

Figure $4 \mid$ SEM images of $(\mathrm{a}, \mathrm{b}) \mathrm{Co}_{3} \mathrm{O}_{4} \mathrm{NAs},(\mathrm{c}, \mathrm{d}) \mathrm{Co}_{3} \mathrm{O}_{4} @ \mathrm{Pt} \mathrm{NAs}$, and (e, f) $\mathrm{Co}_{3} \mathrm{O}_{4} @ \mathrm{Pt} @ \mathrm{MnO}_{2} \mathrm{NAs}$. tailored by varying the deposition time of $\mathrm{MnO}_{2}$ (Figure S2). In particular, Figure $4 \mathrm{e}$ and $3 \mathrm{f}$ are representative SEM images of the $\mathrm{Co}_{3} \mathrm{O}_{4} @ \mathrm{Pt} @ \mathrm{MnO}_{2} \mathrm{NAs}$ prepared by 6 h $\mathrm{MnO}_{2}$ deposition.

More detailed structural information of the $\mathrm{Co}_{3} \mathrm{O}_{4} @ \mathrm{Pt} @ \mathrm{MnO}_{2}$ NAs was provided by transmission electron microscopy (TEM). The TEM samples were prepared by scratching the $\mathrm{Co}_{3} \mathrm{O}_{4} @ \mathrm{Pt} @$ $\mathrm{MnO}_{2}$ NAs from the Ti substrate, followed by dispersing them in ethanol and casting them on the TEM copper grids. Figure $5 \mathrm{a}$ and $5 \mathrm{~b}$ show the typical TEM images of the $\mathrm{Co}_{3} \mathrm{O}_{4} @ \mathrm{Pt} @ \mathrm{MnO}_{2} \mathrm{NAs}$ taken at different magnifications, indicating that porous $\mathrm{Co}_{3} \mathrm{O}_{4}$ nanowires were uniformly covered with small $\mathrm{MnO}_{2}$ nanoflakes. Figure $5 \mathrm{c}$ and $5 \mathrm{~d}$ are enlarged TEM images of the square area 1 and 2 in Figure 5b, respectively. A core-shell-shell structure was observed for a typical $\mathrm{Co}_{3} \mathrm{O}_{4} @ \mathrm{Pt} @ \mathrm{MnO}_{2}$ nanowire (Figure 5c). The thickness of the deposited $\mathrm{Pt}$ nanoparticles and $\mathrm{MnO}_{2}$ nanoflakes was in the range of $10-20$ and $50-100 \mathrm{~nm}$, respectively. The primary $\mathrm{MnO}_{2}$

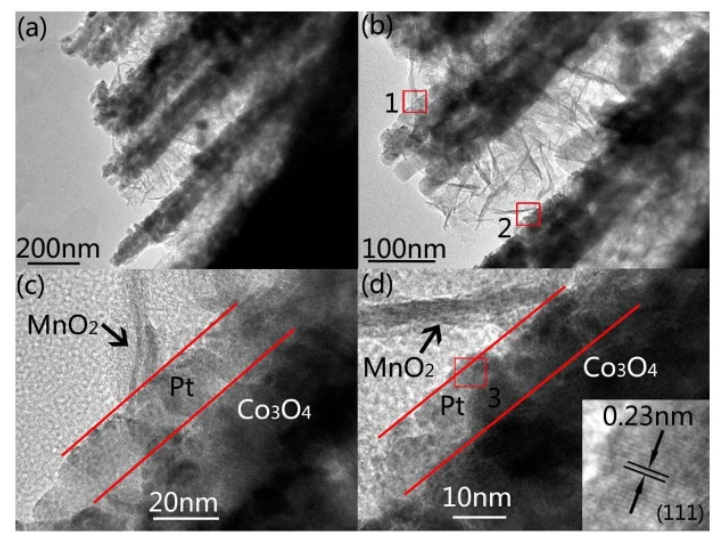

Figure $5 \mid$ TEM images of the $\mathrm{Co}_{3} \mathrm{O}_{4} @ \mathrm{Pt} @ \mathrm{MnO}_{2}$ nanowires taken at different magnifications: (a, b) low-magnification images; (c, d) highmagnification images of the square area 1 and 2 in (b), respectively. The inset in (d) shows a HRTEM image of the square area 3. 


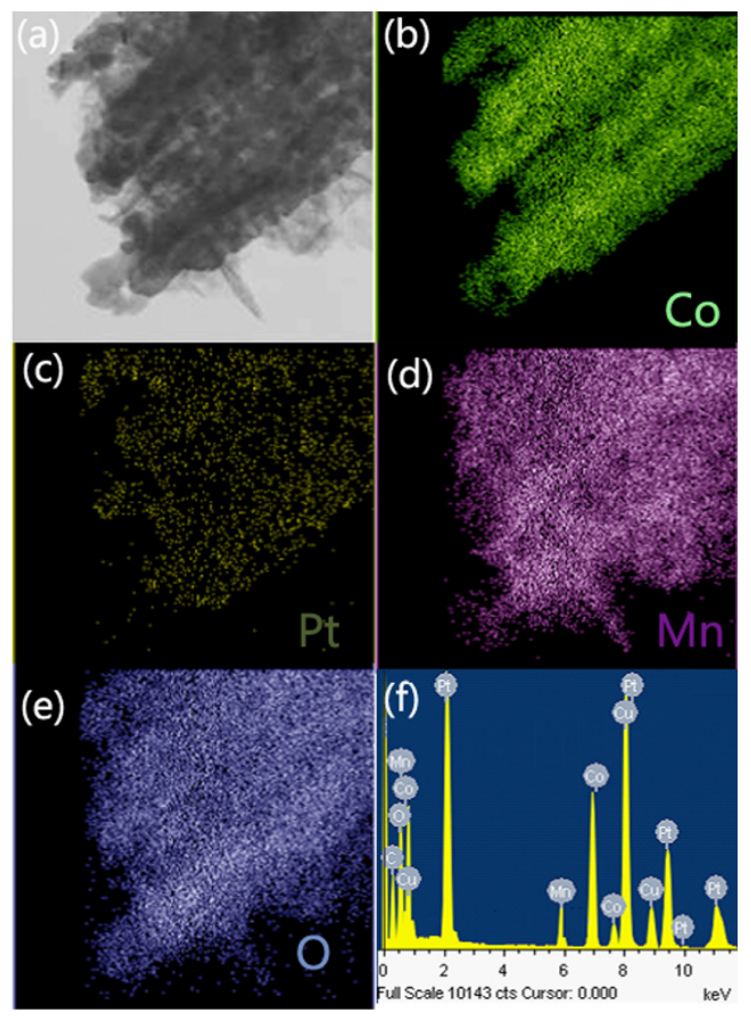

Figure 6 | (a) TEM image of the $\mathrm{Co}_{3} \mathrm{O}_{4} @ \mathrm{Pt} @ \mathrm{MnO}_{2}$ nanowires and EDS element maps of (b) Co, (c) $\mathrm{Pt}$, (d) Mn, and (e) O. (f) EDS spectrum of the $\mathrm{Co}_{3} \mathrm{O}_{4} @ \mathrm{Pt} @ \mathrm{MnO}_{2}$ nanowires.

nanoflakes were ultrathin and had a thickness of $\sim 5 \mathrm{~nm}$, as shown in Figure $5 \mathrm{c}$ and $5 \mathrm{~d}$. The inset of Figure $5 \mathrm{~d}$ is the high-resolution TEM image of the square area 3 , showing single crystallinity and the $<111>$ direction of $\mathrm{Pt}$ nanoparticles. The lattice spacing between the (111) planes, $0.23 \mathrm{~nm}$, is the same as that of bulk $\mathrm{Pt}^{41,42}$. In contrast, no clear lattice fringes could be observed for the $\mathrm{MnO}_{2}$ nanoflakes (Figure S3), corroborating the amorphous nature of $\mathrm{MnO}_{2}$, which is similar to the observation in its XRD patterns. Elemental mapping by energy-dispersive X-ray spectroscopy (EDS) (Figure 6) confirmed the core-shell hierarchical structure of the $\mathrm{Co}_{3} \mathrm{O}_{4} @ \mathrm{Pt} @ \mathrm{MnO}_{2}$ nanowires. The EDS spectrum (Figure 6f) also supports the incorporation of Pt between the $\mathrm{MnO}_{2}$ shell and $\mathrm{Co}_{3} \mathrm{O}_{4}$ core. $\mathrm{Cu}$ and $\mathrm{C}$ signals in Figure $6 \mathrm{f}$ are from the TEM copper grid.

The electrochemical performance of the $\mathrm{Co}_{3} \mathrm{O}_{4} @ \mathrm{Pt} @ \mathrm{MnO}_{2} \mathrm{NAs}$ was first examined by cyclic voltammetry $(\mathrm{CV})$ by using an aqueous solution of $\mathrm{Na}_{2} \mathrm{SO}_{4}(1.0 \mathrm{M})$ as the electrolyte. The $\mathrm{CV}$ curves of the $\mathrm{Co}_{3} \mathrm{O}_{4} @ \mathrm{Pt} @ \mathrm{MnO}_{2} \mathrm{NA}$ electrode were recorded at scan rates of 10, 25, 50, and $100 \mathrm{mV} / \mathrm{s}$. As shown in Figure 7a, all CV curves displayed a quasi-rectangular shape with a perfect mirror-image feature, suggesting that the $\mathrm{Co}_{3} \mathrm{O}_{4} @ \mathrm{Pt} @ \mathrm{MnO}_{2}$ NAs have an ideal capacitive behavior and high rate capability ${ }^{26,43}$. In contrast, the rectangularity of CV curves of the bare $\mathrm{MnO}_{2}$ thin film electrode (Figure $7 \mathrm{~b}$ ) was remarkably distorted, especially at a high scan rate of $100 \mathrm{mV} / \mathrm{s}$. The current densities of the CV curves of the $\mathrm{Co}_{3} \mathrm{O}_{4} @ \mathrm{Pt} @ \mathrm{MnO}_{2} \mathrm{NA}$ electrode were much higher than those of the bare $\mathrm{MnO}_{2}$ thin film electrode. Moreover, the CV curve of the $\mathrm{Co}_{3} \mathrm{O}_{4} @ \mathrm{Pt}_{\mathrm{t}} @ \mathrm{MnO}_{2} \mathrm{NA}$ electrode at the scan rate of $50 \mathrm{mV} / \mathrm{s}$ (Figure 7c) had a much larger integrated area compared to that of the bare $\mathrm{MnO}_{2}$ thin film electrode, which suggests that a much higher specific capacitance was achieved in the $\mathrm{Co}_{3} \mathrm{O}_{4} @ \mathrm{Pt} @ \mathrm{MnO}_{2} \mathrm{NA}$ electrode. Since the capacitance contribution of $\mathrm{Co}_{3} \mathrm{O}_{4}$ and $\mathrm{Pt}$ was small and can be neglected, the specific capacitance of the $\mathrm{Co}_{3} \mathrm{O}_{4} @ \mathrm{Pt} @ \mathrm{MnO}_{2} \mathrm{NA}$ electrode was calculated on the $\mathrm{MnO}_{2}$ mass basis. As shown in Figure $7 \mathrm{~d}$, the $\mathrm{Co}_{3} \mathrm{O}_{4} @ \mathrm{Pt} @ \mathrm{MnO}_{2} \mathrm{NA}$ electrode had a specific capacitance of 497, 435,393 , and $354 \mathrm{~F} / \mathrm{g}$ at scan rates of $10,25,50$, and $100 \mathrm{mV} / \mathrm{s}$, respectively, which were about 3 -fold of increase than those of the bare $\mathrm{MnO}_{2}$ thin film electrode. For example, at the scan rate of $10 \mathrm{mV} / \mathrm{s}$, the $\mathrm{Co}_{3} \mathrm{O}_{4} @ \mathrm{Pt} @ \mathrm{MnO}_{2} \mathrm{NA}$ electrode delivered a specific capacitance of $497 \mathrm{~F} / \mathrm{g}$. By comparison, the bare $\mathrm{MnO}_{2}$ thin film electrode can only provide the specific capacitance of $133 \mathrm{~F} / \mathrm{g}$. Among all $\mathrm{Co}_{3} \mathrm{O}_{4} @ \mathrm{Pt} @ \mathrm{MnO}_{2} \mathrm{NAs}$ prepared by different $\mathrm{MnO}_{2}$ deposition times, the one prepared by $6 \mathrm{~h} \mathrm{MnO}_{2}$ deposition had the best electrochemical performance (Table S1), combining the merits of both high specific capacitance and good $\mathrm{MnO}_{2}$ loading.
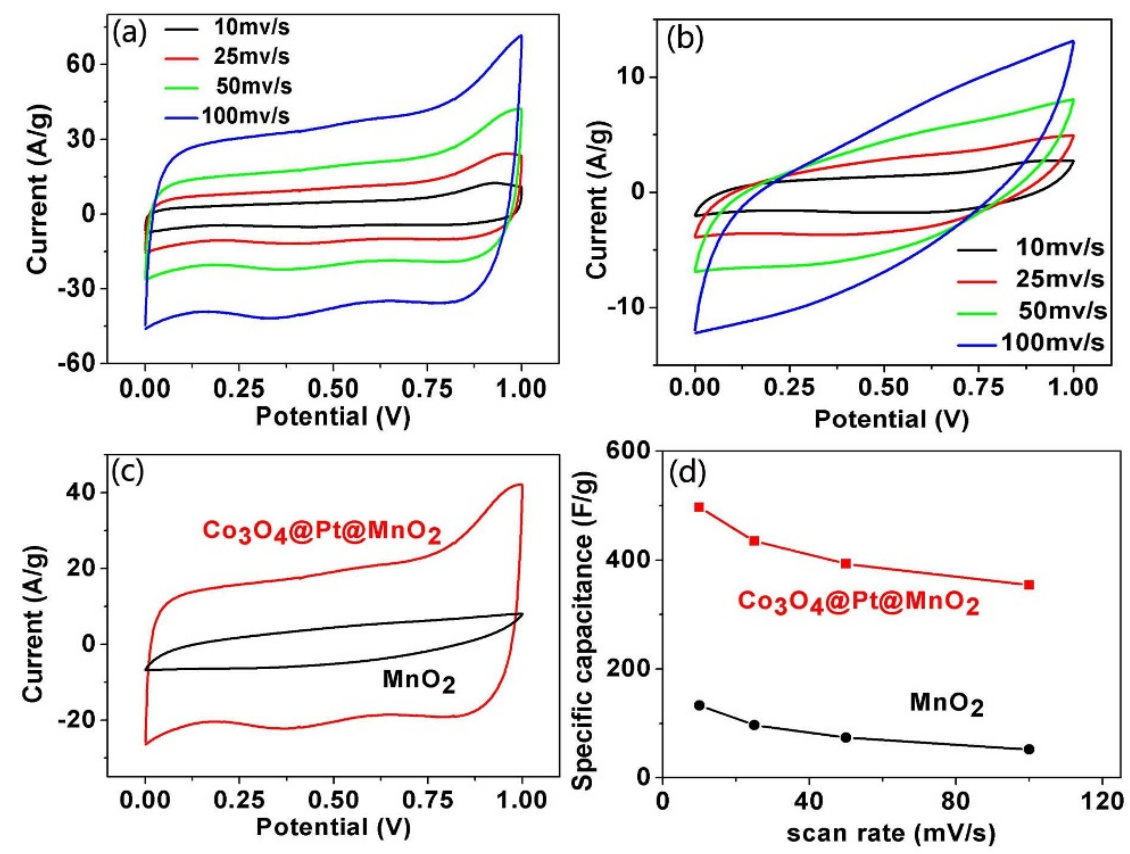

Figure 7 Cyclic voltammograms of (a) $\mathrm{Co}_{3} \mathrm{O}_{4} @ \mathrm{Pt} @ \mathrm{MnO}_{2} \mathrm{NA}$ electrode and (b) $\mathrm{MnO}_{2}$ thin film electrode at different scan rates in an aqueous solution of $\mathrm{Na}_{2} \mathrm{SO}_{4}(1 \mathrm{M})$. (c) Comparison of the CV curves of $\mathrm{Co}_{3} \mathrm{O}_{4} @ \mathrm{Pt} @ \mathrm{MnO}_{2} \mathrm{NA}$ electrode (red) and $\mathrm{MnO}_{2}$ thin film electrode (black) at a scan rate of $50 \mathrm{mV} / \mathrm{s}$. (d) Specific capacitances of $\mathrm{Co}_{3} \mathrm{O}_{4} @ \mathrm{Pt} @ \mathrm{MnO}_{2} \mathrm{NA}$ electrode (red) and $\mathrm{MnO}_{2}$ thin film electrode (black) at different scan rates. 
For example, further increasing the $\mathrm{MnO}_{2}$ deposition time to $10 \mathrm{~h}$, the specific capacitance per gram of the $\mathrm{Co}_{3} \mathrm{O}_{4} @ \mathrm{Pt} @ \mathrm{MnO}_{2} \mathrm{NA}$ electrode decreased to $210.3 \mathrm{~F} / \mathrm{g}$ (Figure S5 and Table S1).

The $\mathrm{Co}_{3} \mathrm{O}_{4} @ \mathrm{Pt} @ \mathrm{MnO}_{2} \mathrm{NA}$ electrode showed an impressive rate capability (Figure 8). A good symmetry and fairly linear slopes were observed in the galvanostatic charge-discharge curves of the $\mathrm{Co}_{3} \mathrm{O}_{4} @$ $\mathrm{Pt} @ \mathrm{MnO}_{2} \mathrm{NA}$ electrode at current densities of 1-40 A/g, indicating a good electrochemical capacitive characteristic and superior reversible redox reaction. Figure $8 \mathrm{~b}$ compares the charge-discharge curves of the $\mathrm{Co}_{3} \mathrm{O}_{4} @ \mathrm{Pt} @ \mathrm{MnO}_{2} \mathrm{NA}$ and $\mathrm{MnO}_{2}$ thin film electrodes at the current density of $1 \mathrm{~A} / \mathrm{g}$. The charge storage capacity of the $\mathrm{Co}_{3} \mathrm{O}_{4} @$ $\mathrm{Pt} @ \mathrm{MnO}_{2} \mathrm{NA}$ electrode was significantly higher than that of the $\mathrm{MnO}_{2}$ thin film electrode with a 235\% increase in the discharge time. In addition, the internal resistance (IR) of the $\mathrm{Co}_{3} \mathrm{O}_{4} @ \mathrm{Pt} @ \mathrm{MnO}_{2} \mathrm{NA}$ electrode (the IR drop is $0.0016 \mathrm{~V}$ ) was significantly reduced compared to that of the $\mathrm{MnO}_{2}$ thin film electrode (the drop is $0.065 \mathrm{~V}$ ). Figure $8 \mathrm{c}$ compares the specific capacitances of the two electrodes derived from the discharging curves at different current densities. The $\mathrm{Co}_{3} \mathrm{O}_{4} @ \mathrm{Pt} @ \mathrm{MnO}_{2} \mathrm{NA}$ electrode delivered a specific capacitance of $539 \mathrm{~F} / \mathrm{g}$ at the current density of $1 \mathrm{~A} / \mathrm{g}$. This value was much higher than that of the $\mathrm{MnO}_{2}$ thin film electrode $(171 \mathrm{~F} / \mathrm{g})$. In addition, the specific capacitance of our electrode is comparable to the reported values in the high-performance $\mathrm{MnO}_{2}$-based hybrid electrodes, such as graphene/ $\mathrm{MnO}_{2}$ (with a specific capacitance of $\sim 380 \mathrm{~F} / \mathrm{g}$ ) and $\mathrm{Zn}_{2} \mathrm{SnO}_{4} @ \mathrm{MnO}_{2}$ (with a specific capacitance of $\sim 621 \mathrm{~F} / \mathrm{g}$ ) electrodes ${ }^{44,26}$. In addition, at a high current density of $40 \mathrm{~A} / \mathrm{g}$, the $\mathrm{Co}_{3} \mathrm{O}_{4} @ \mathrm{Pt} @ \mathrm{MnO}_{2} \mathrm{NA}$ electrode still delivered a high specific capacitance of $298.1 \mathrm{~F} / \mathrm{g}$, or $\sim 55.3 \%$ of the specific capacitance at $1 \mathrm{~A} / \mathrm{g}$, indicating its superior rate capability.

Power density and energy density are two key performance indicators of supercapacitors. Figure $8 \mathrm{~d}$ compares the Ragone plots of the $\mathrm{Co}_{3} \mathrm{O}_{4} @ \mathrm{Pt} @ \mathrm{MnO}_{2} \mathrm{NA}$ and $\mathrm{MnO}_{2}$ thin film electrodes, showing that the power and energy densities of the $\mathrm{Co}_{3} \mathrm{O}_{4} @ \mathrm{Pt} @ \mathrm{MnO}_{2} \mathrm{NAs}$ were much higher than that of the $\mathrm{MnO}_{2}$ thin film. In addition, as the current density increased from 1 to $40 \mathrm{~A} / \mathrm{g}$, the energy density of the $\mathrm{Co}_{3} \mathrm{O}_{4} @ \mathrm{Pt} @ \mathrm{MnO}_{2} \mathrm{NA}$ electrode decreased from 74.6 to
39.6 Wh $/ \mathrm{kg}$, and its power density, on the contrary, increased from 0.5 to $19.6 \mathrm{~kW} / \mathrm{kg}$.

Cycling stability is another key performance indicator of supercapacitors. Figure 9a compares the cycling performance of the $\mathrm{Co}_{3} \mathrm{O}_{4} @ \mathrm{Pt} @ \mathrm{MnO}_{2} \mathrm{NA}$ and $\mathrm{MnO}_{2}$ thin film electrodes at the current density of $5 \mathrm{~A} / \mathrm{g}$ over 5000 cycles. The specific capacitance of the $\mathrm{Co}_{3} \mathrm{O}_{4} @ \mathrm{Pt} @ \mathrm{MnO}_{2} \mathrm{NA}$ electrode increased slightly for the initial several hundreds of cycles and was relatively constant from the cycles onwards, indicating an excellent stability for the $\mathrm{Co}_{3} \mathrm{O}_{4} @ \mathrm{Pt} @ \mathrm{MnO}_{2}$ NA electrode. After 5000 cycles, the specific capacitance was still slightly larger than the value of the first cycle, corresponding to a capacitance retention of $\sim 105.6 \%$. In addition, no obvious dissolution of $\mathrm{MnO}_{2}$ nanoflakes in the electrolyte was observed during cycling, as suggested by the unchanged transparent electrolyte solution during cycling ${ }^{21,22,45}$. A slight increase of the specific capacitance of the $\mathrm{Co}_{3} \mathrm{O}_{4} @ \mathrm{Pt} @ \mathrm{MnO}_{2} \mathrm{NA}$ electrode after the first cycle was due to the activation of the electrode via increasing the contact area between the electrode and the electrolyte during cycling. In contrast, only $89.8 \%$ of the initial capacitance was retained for the $\mathrm{MnO}_{2}$ thin film electrode. The current density dependence of the cycling performance of the $\mathrm{Co}_{3} \mathrm{O}_{4} @ \mathrm{Pt} @ \mathrm{MnO}_{2} \mathrm{NA}$ electrode was also evaluated from 5 to $20 \mathrm{~A} / \mathrm{g}$. Figure $9 \mathrm{~b}$ shows a very good cycling behavior of the $\mathrm{Co}_{3} \mathrm{O}_{4} @ \mathrm{Pt} @ \mathrm{MnO}_{2} \mathrm{NA}$ electrode at these current densities. In addition, the specific capacitance was fully recovered at $5 \mathrm{~A} / \mathrm{g}$ after cycling at those higher rates, and no noticeable decrease was observed after another 300 cycles.

\section{Discussion}

It is worth mentioning that the intermediate $\mathrm{Pt}$ nanoparticle layer is crucial for the construction of the core-shell-shell $\mathrm{Co}_{3} \mathrm{O}_{4} @ \mathrm{Pt} @ \mathrm{MnO}_{2}$ nanowires. The $\mathrm{Pt}$ nanoparticle layer on the $\mathrm{Co}_{3} \mathrm{O}_{4}$ nanowires was used to confine the growth of $\mathrm{MnO}_{2}$ nanoflakes on the nanowire surface during the chemical bath deposition. Without the help from the Pt layer, no $\mathrm{MnO}_{2}$ layer can be deposited on the surface of $\mathrm{Co}_{3} \mathrm{O}_{4}$ nanowires, and only agglomerated $\mathrm{MnO}_{2}$ spheres attaching on the top of the $\mathrm{Co}_{3} \mathrm{O}_{4}$ nanowires were obtained (Figure S4). A similar
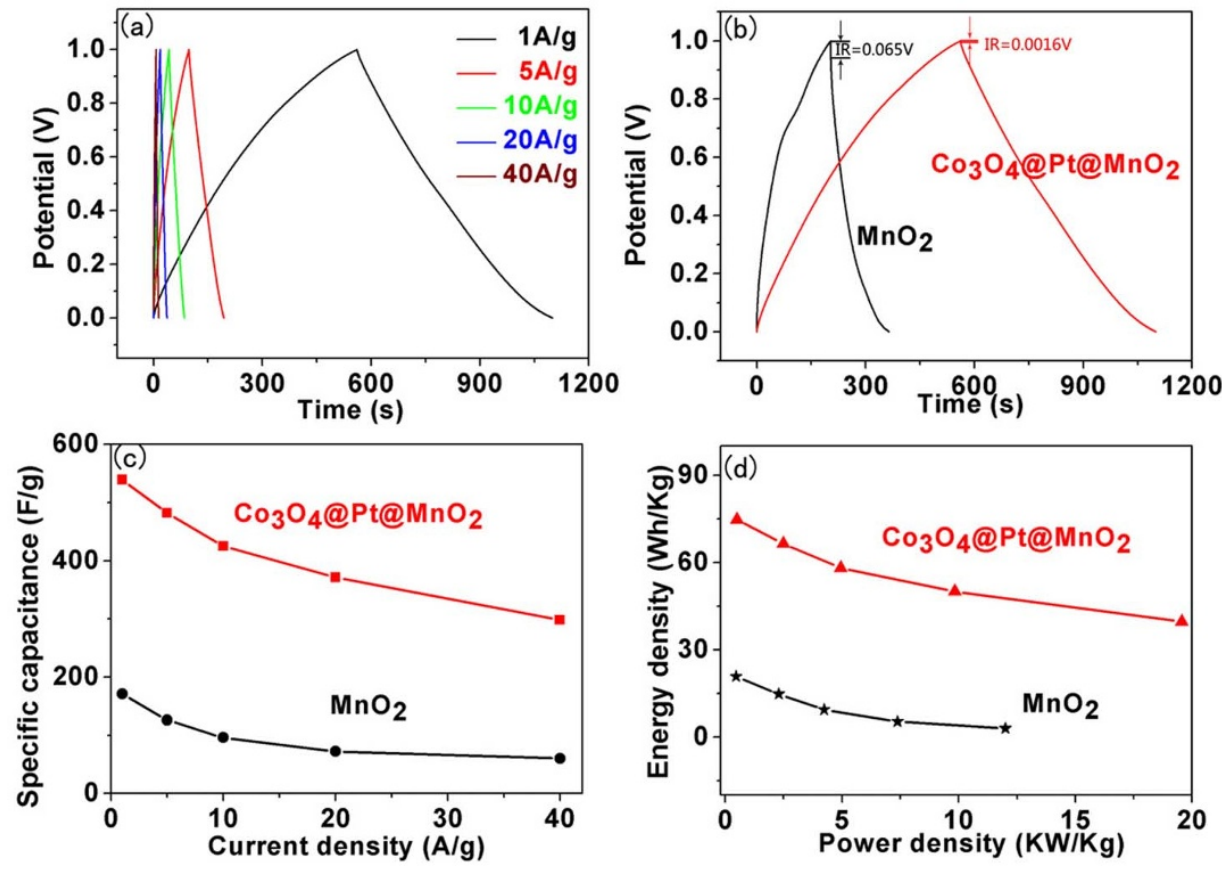

Figure 8 (a) Charge-discharge curves of $\mathrm{Co}_{3} \mathrm{O}_{4} @ \mathrm{Pt} @ \mathrm{MnO}_{2} \mathrm{NA}$ electrode at different current densities. (b) Comparison of charge-discharge curves of $\mathrm{Co}_{3} \mathrm{O}_{4} @ \mathrm{Pt} @ \mathrm{MnO}_{2} \mathrm{NA}$ electrode (red) and $\mathrm{MnO}_{2}$ thin film electrode (black) at a current density of $1 \mathrm{~A} / \mathrm{g}$. (c) Specific capacitances of $\mathrm{Co}_{3} \mathrm{O}_{4} @ \mathrm{Pt} @ \mathrm{MnO}_{2} \mathrm{NA}$ electrode (red) and $\mathrm{MnO}_{2}$ thin film electrode (black) at different scan rates. (d) Ragone plots of $\mathrm{Co}_{3} \mathrm{O}_{4} @ \mathrm{Pt} @ \mathrm{MnO}_{2} \mathrm{NA}$ electrode (red) and $\mathrm{MnO}_{2}$ thin film electrode (black). 

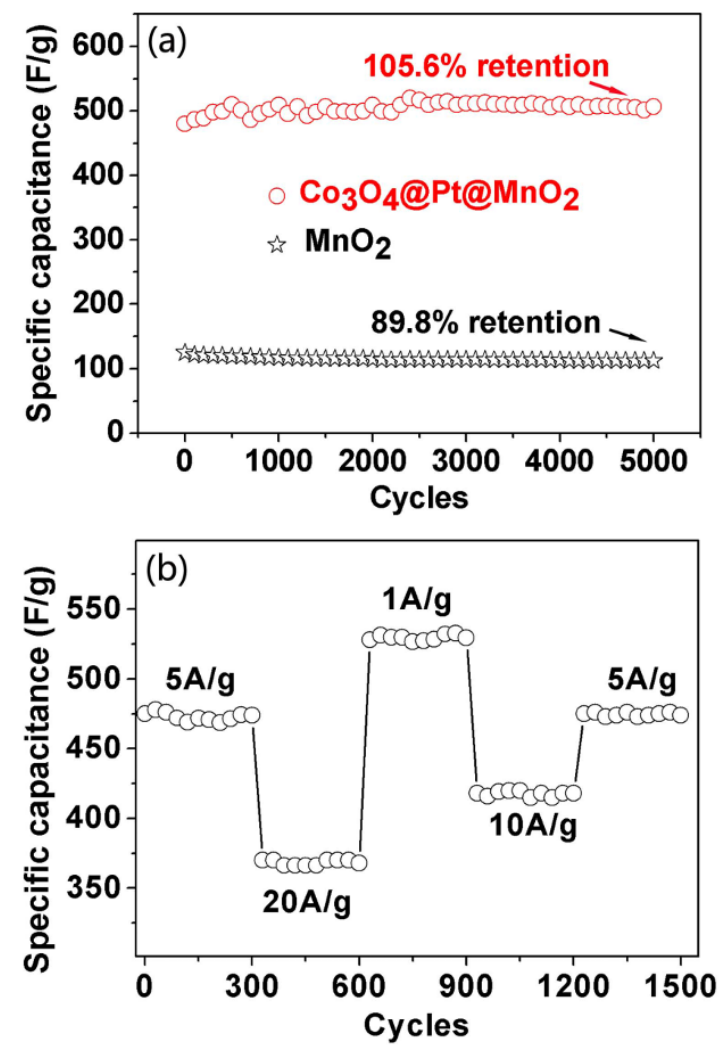

Figure 9 $\mid$ (a) Cycling performance of $\mathrm{Co}_{3} \mathrm{O}_{4} @ \mathrm{Pt} @ \mathrm{MnO}_{2} \mathrm{NA}$ electrode (red) and $\mathrm{MnO}_{2}$ thin film electrode (black) at a current density of $5 \mathrm{~A} / \mathrm{g}$. (b) Cycling stability of $\mathrm{Co}_{3} \mathrm{O}_{4} @ \mathrm{Pt} @ \mathrm{MnO}_{2} \mathrm{NA}$ electrode at different current densities.

observation was reported by Liu et al. They deposited a carbon layer on the $\mathrm{Co}_{3} \mathrm{O}_{4} \mathrm{NWs}$, which could subsequently react with $\mathrm{KMnO}_{4}$, leading to the formation of $\mathrm{MnO}_{2}$ on the $\mathrm{Co}_{3} \mathrm{O}_{4} \mathrm{NWs}^{29}$. In the present study, the confinement role of the Pt nanoparticle layer for $\mathrm{MnO}_{2}$ deposition can be attributed to the preferred nucleation of $\mathrm{MnO}_{2}$ on the Pt nanoparticle surface compared to the homogeneous nucleation in solution during the chemical bath deposition, similar to the findings reported in a previous study ${ }^{43}$. Moreover, $\mathrm{Co}_{3} \mathrm{O}_{4}$ is a ptype semiconductor with an electrical conductivity in the range of $10^{-4}$ to $10^{-2} \mathrm{~S} / \mathrm{cm}^{46}$. This value is much lower than that of a noble metal (e.g., the electrical conductivity of $\mathrm{Pt}$ is $\left.\sim 10^{6} \mathrm{~S} / \mathrm{cm}\right)^{47}$. Therefore, although the incorporation of $\mathrm{Co}_{3} \mathrm{O}_{4} \mathrm{NWs}$ in our hybrid electrode can improve the loading efficiency of the nanosturctured $\mathrm{MnO}_{2}$, it may still suffer with the poor conductivity between the $\mathrm{MnO}_{2}$ and the current collector. This constraint has been successfully addressed by the smart incorporation of an intermediate $\mathrm{Pt}$ nanoparticle layer in our hybrid electrode, which provides a good electrical conductivity, thus leading to a good electrical performance including a large specific capacitance and a good rate capability.

The high specific capacitance and superior rate capability had much to be credited to the hierarchical architecture and the synergy of the three key components in the $\mathrm{Co}_{3} \mathrm{O}_{4} @ \mathrm{Pt} @ \mathrm{MnO}_{2}$ NAs. First, a highly porous structure was created by growing small $\mathrm{MnO}_{2}$ nanoflakes on the $\mathrm{Co}_{3} \mathrm{O}_{4} @ \mathrm{Pt}$ scaffold, which not only increased the utilization of active $\mathrm{MnO}_{2}$ owing to the small size feature of the $\mathrm{MnO}_{2}$ nanoflakes, but also benefited the penetration of the electrolyte due to the highly porous structure. These two effects are essential to the high specific capacitance of the $\mathrm{Co}_{3} \mathrm{O}_{4} @ \mathrm{Pt} @ \mathrm{MnO}_{2} \mathrm{NAs}$ considering the charge storage of $\mathrm{MnO}_{2}$ is a surface or near-surface process. Second, the thin and well-separated $\mathrm{MnO}_{2}$ nanoflakes could shorten the electron and ion diffusion paths, and make possible fast and reversible redox reactions, thus enhancing the electrochemical kinetics. Third, a thin layer of $\mathrm{Pt}$ nanoparticles between the $\mathrm{Co}_{3} \mathrm{O}_{4}$ and $\mathrm{MnO}_{2}$ layer could further improve the transport and collection of electrons, leading to a fast charge-discharge rate. Furthermore, the NAs directly grown on the Ti substrate had excellent mechanical adhesion and electrical connection to the current collector, and the polymer binders or conductive additives were not required. In general, the use of the polymer binders or conductive additives might increase the "dead volume" in the electrode materials ${ }^{29,48}$.

The electrochemical impedance spectra (EIS) of the $\mathrm{Co}_{3} \mathrm{O}_{4} @ \mathrm{Pt} @$ $\mathrm{MnO}_{2} \mathrm{NAs}$ and $\mathrm{MnO}_{2}$ thin film electrodes were also measured to provide further insights. The Nyquist plots in Figure 10 for the $\mathrm{Co}_{3} \mathrm{O}_{4} @ \mathrm{Pt} @ \mathrm{MnO}_{2} \mathrm{NA}$ and $\mathrm{MnO}_{2}$ thin film electrodes show a straight line in the low frequency region, a depressed semicircle in the high-to-medium frequency region, and a high frequency intercept in the real $\mathrm{Z}^{\prime}$ axis. Almost the same high frequency intercepts were observed for the two electrodes, indicating that they had the same overall ohmic resistance (the combination of the ionic resistance of the electrolyte, the intrinsic resistance of the active materials, and the contact resistance between the active materials and the current collector). The semicircle in the high-to-medium frequency region represents the parallel combination of the charge-transfer resistance $\left(R_{\mathrm{ct}}\right)$ and double-layer capacitance. The size of the semicircle, which equals to $R_{\mathrm{ct}}$, was clearly smaller for the $\mathrm{Co}_{3} \mathrm{O}_{4} @ \mathrm{Pt} @$ $\mathrm{MnO}_{2}$ NA electrode $(\sim 3 \Omega)$ compared to that of the $\mathrm{MnO}_{2}$ thin film electrode $(\sim 300 \Omega)$. The large surface area and improved electrical conductivity of the $\mathrm{Co}_{3} \mathrm{O}_{4} @ \mathrm{Pt} @ \mathrm{MnO}_{2} \mathrm{NA}$ electrode could be the main reason for the reduction of the charge-transfer resistance. The straight line in the low frequency region corresponds to the diffusion-controlled region, where a finite slope represents the diffusive resistance of the electrolyte in the electrode pores and the cation diffusion in the host materials ${ }^{49,50}$. The slope of the straight line was obviously larger for the $\mathrm{Co}_{3} \mathrm{O}_{4} @ \mathrm{Pt} @ \mathrm{MnO}_{2} \mathrm{NA}$ electrode compared to that of the $\mathrm{MnO}_{2}$ thin film electrode, indicating a lower diffusive resistance for the $\mathrm{Co}_{3} \mathrm{O}_{4} @ \mathrm{Pt} @ \mathrm{MnO}_{2} \mathrm{NA}$ electrode.

In summary, a novel hierarchical $\mathrm{Co}_{3} \mathrm{O}_{4} @ \mathrm{Pt} @ \mathrm{MnO}_{2}$ nanostructure was fabricated by a facile strategy in this study. The complemental features of the three key components: a well-defined $\mathrm{Co}_{3} \mathrm{O}_{4}$ NA on the conductive Ti substrate (good conductivity), an ultrathin layer of small Pt nanoparticles (further enhancing the conductivity), and a thin layer of $\mathrm{MnO}_{2}$ nanoflakes (large surface area), have been combined to construct a high-performance electrode for supercapacitors. Hence high specific capacitances [e.g., $539 \mathrm{~F} / \mathrm{g}$ at $1 \mathrm{~A} / \mathrm{g}$ in an aqueous $\mathrm{Na}_{2} \mathrm{SO}_{4}$ solution $(1 \mathrm{M})$ ], good rate capability (a specific

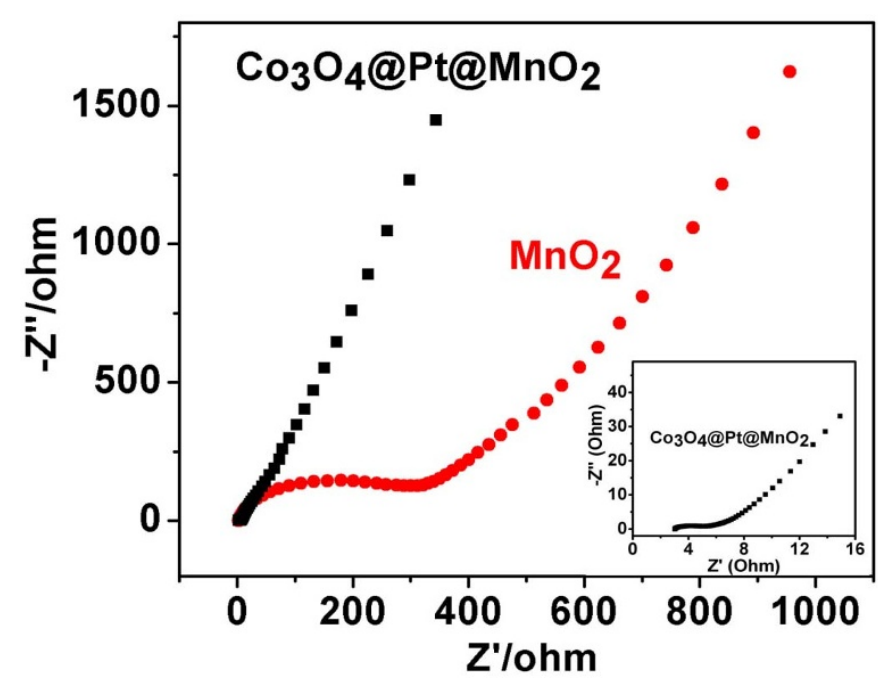

Figure $10 \mid$ Nyquist plots of $\mathrm{Co}_{3} \mathrm{O}_{4} @ \mathrm{Pt} @ \mathrm{MnO}_{2} \mathrm{NA}$ electrode (black) and $\mathrm{MnO}_{2}$ thin film electrode (red). The inset is the enlarged impedance spectrum of $\mathrm{Co}_{3} \mathrm{O}_{4} @ \mathrm{Pt} @ \mathrm{MnO}_{2} \mathrm{NA}$ electrode at high frequencies. 
energy and power density of $39.6 \mathrm{Wh} / \mathrm{kg}$ and $19.6 \mathrm{~kW} / \mathrm{kg}$ at $40 \mathrm{~A} / \mathrm{g}$, respectively), and excellent cycling stability (no capacity loss over 5000 cycles) were achieved in the as-fabricated $\mathrm{Co}_{3} \mathrm{O}_{4} @ \mathrm{Pt} @ \mathrm{MnO}_{2}$ NA electrode. The architectural design developed herein therefore provides an efficient way to improve the electrochemical performance of $\mathrm{MnO}_{2}$-based electrodes for supercapacitors.

\section{Methods}

Fabrication of $\mathrm{Co}_{3} \mathrm{O}_{4} @ \mathrm{Pt} @ \mathrm{MnO}_{2}$ NAs. $\mathrm{Co}_{3} \mathrm{O}_{4}$ NAs were grown on the Ti foil by a common hydrothermal method according to a previous publication ${ }^{30}$. A thin film of Pt nanoparticles was then coated on the $\mathrm{Co}_{3} \mathrm{O}_{4}$ NAs by using a sputter-coater JS1600. After that, a thin $\mathrm{MnO}_{2}$ layer was deposited onto the surface of $\mathrm{Co}_{3} \mathrm{O}_{4} @ \mathrm{Pt}$ NAs via a facile chemical bath deposition method ${ }^{43}$. In a typical $\mathrm{MnO}_{2}$ deposition process, the Ti foil grown with $\mathrm{Co}_{3} \mathrm{O}_{4} @ \mathrm{Pt}$ NAs was submerged into an aqueous solution $(30 \mathrm{~mL}$, $25^{\circ} \mathrm{C}$ ) of $\mathrm{MnSO}_{4} \cdot \mathrm{H}_{2} \mathrm{O},\left(\mathrm{NH}_{4}\right)_{2} \mathrm{~S}_{2} \mathrm{O}_{8}$, and $\mathrm{Na}_{2} \mathrm{SO}_{4}$ (molar ratio of $1: 1: 1$, and the concentration was $0.1 \mathrm{~mol} / \mathrm{L}$ ). The mixture was stirring at room temperature for 2 to $10 \mathrm{~h}$, which led to 0.1 to $0.3 \mathrm{mg} \mathrm{MnO}_{2}$ deposited on the nanowire surface on the Ti foil. The as-fabricated $\mathrm{Co}_{3} \mathrm{O}_{4} @ \mathrm{Pt} @ \mathrm{MnO}_{2} \mathrm{NAs}$ were then washed with copious water and subsequently dried at $60^{\circ} \mathrm{C}$ in an oven. For comparison, a planar $\mathrm{MnO}_{2}$ thin film was also fabricated on the $\mathrm{Ti}$ foil by the anodic deposition according to published procedures $^{51}$

Materials characterization. The microstructure, surface morphology, and chemical composition of the samples were characterized using powder X-ray diffraction (XRD), X-ray photoelectron spectroscopy (XPS), field emission scanning electron microscopy (FESEM), transmission electron microscopy (TEM), and high-resolution transmission electron microscopy (HRTEM). The powder XRD measurements were performed on a Bruker D8 advanced diffractometer with a $\mathrm{Cu} K \alpha$ radiation in the $2 \theta$ range of $10-80^{\circ}$. XPS spectra were recorded on a Phi Quantera spectrometer using A1 $K \alpha \mathrm{X}$-ray as the excitation source. FESEM and TEM images were taken on a Hitachi S4800 microscope and a JEOL JEM2100 microscope equipped with an Energy Dispersive Spectroscopy (EDS), respectively.

Electrochemical measurements. Electrochemical measurements were performed on an electrochemical workstation (CHI 660D, CH Instruments Inc., Shanghai). The three-electrode cell with $\mathrm{Ag} / \mathrm{AgCl}$ as the reference electrode, $\mathrm{Pt}$ foil as the counter electrode, and the as-fabricated samples as the working electrode, was used for the electrochemical measurements. $1 \mathrm{M} \mathrm{Na}_{2} \mathrm{SO}_{4}$ was used as the electrolyte. $\mathrm{CV}$ measurements were carried out between 0 and $1 \mathrm{~V}$ at different scan rates of 10,25,50, and $100 \mathrm{mV} / \mathrm{s}$. Galvanostatic charge-discharge measurements were used to evaluate the power and energy densities at different current densities of 1,5, 10, 20, and $40 \mathrm{~A} / \mathrm{g}$. Electrochemical impedance spectroscopy (EIS) was performed by applying an AC voltage of $5 \mathrm{mV}$ in a frequency range of $0.01 \mathrm{~Hz}$ to $100 \mathrm{KHz}$ at an open circuit potential.

1. Wang, X. J. et al. An Aqueous Rechargeable Lithium Battery Using Coated Li Metal as Anode. Sci. Rep. 3, 1401 (2013).

2. Liu, C., Li, F., Ma, L. P. \& Cheng, H. M. Advanced Materials for Energy Storage. Adv. Mater. 22, E28-E62 (2010).

3. Song, Z. P. et al. Polymer-Graphene Nanocomposites as Ultrafast-Charge and Discharge Cathodes for Rechargeable Lithium Batteries. Nano Lett. 12, 2205-2211 (2012).

4. Xu, B., Qian, D., Wang, Z. Y. \& Meng, Y. S. Recent Progress in Cathode Materials Research for Advanced Lithium Ion Batteries. Mater. Sci. Eng. R. 73, 51-65 (2012).

5. Lim, H. D. et al. Enhanced Power and Rechargeability of a $\mathrm{Li}_{-} \mathrm{O}_{2}$ Battery Based on a Hierarchical-Fibril CNT Electrode. Adv. Mater. 25, 1348-1352 (2013).

6. Deng, D. \& Lee, J. Y. Reversible Storage of Lithium in a Rambutan-Like TinCarbon Electrode. Angew. Chem. Int. Ed. 48, 1660-1663 (2009).

7. Tang, Z., Tang, C. H. \& Gong, H. A High Energy Asymmetric Supercapacitor from Nano-architectured $\mathrm{Ni}(\mathrm{OH})_{2} /$ Carbon Nanotube Electrodes. Adv. Funct. Mater. 22, 1272-1278 (2012).

8. Lei, Z. B., Lu, L. \& Zhao, X. S. The Electrocapacitive Properties of Graphene Oxide Reduced by Urea. Energy Environ. Sci. 5, 6391-6399 (2012).

9. Chen, S. et al. Graphene Oxide- $\mathrm{MnO}_{2}$ Nanocomposites for Supercapacitors. ACS Nano. 4, 2822-2830 (2010).

10. Yuan, C. Z. et al. Flexible Hybrid Paper Made of Monolayer $\mathrm{Co}_{3} \mathrm{O}_{4}$ Microsphere Arrays on rGO/CNTs and Their Application in Electrochemical Capacitors. Adv. Funct. Mater. 22, 2560-2566 (2012).

11. Zhang, Y. J. et al. Crystallization Design of $\mathrm{MnO}_{2}$ Towards Better Supercapacitor. CrystEngComm. 14, 5892-5897 (2012).

12. Xia, H. et al. A Symmetric $\mathrm{RuO}_{2} / \mathrm{RuO}_{2}$ Supercapacitor Operating at $1.6 \mathrm{~V}$ by Using a Neutral Aqueous Electrolyte. Electrochem. Solid State Lett. 15, A60-A63 (2012).

13. Tang, C. H., Tang, Z. \& Gong, H. Hierarchically Porous Ni-Co Oxide for High Reversibility Asymmetric Full-Cell Supercapacitors. J. Electrochem. Soc. 159, A651-A656 (2012).
14. Xia, X. F. et al. Nanostructured Ternary Composites of Graphene $/ \mathrm{Fe}_{2} \mathrm{O}_{3}$ / Polyaniline for High-performance Supercapacitors. J. Mater. Chem. 22, 16844-16850 (2012).

15. Wang, W. J. et al. Graphene/ $\mathrm{SnO}_{2} /$ Polypyrrole Ternary Nanocomposites as Supercapacitor Electrode Materials. RSC Adv. 2, 10268-10274 (2012).

16. Tang, W. et al. A Hybrid of $\mathrm{MnO}_{2}$ Nanowires and MWCNTs as Cathode of Excellent Rate Capability for Supercapacitors. J. Power Sources. 197, 330-333 (2012).

17. Huang, H. J. \& Wang, X. Graphene Nanoplate- $\mathrm{MnO}_{2}$ Composites for Supercapacitors: a Controllable Oxidation Approach. Nanoscale 3, 3185-3191 (2011).

18. Xu, C. J., Kang, F. Y., Li, B. H. \& Du, H. D. Recent Progress on Manganese Dioxide Based Supercapacitors. J. Mater. Res. 25, 1421-1432 (2010).

19. Pang, H. et al. Cu Superstructures Fabricated Using Tree Leaves and $\mathrm{Cu}-\mathrm{MnO}_{2}$ Superstructures for High Performance Supercapacitors. J. Mater. Chem. A 1 , 5053-5060 (2013).

20. Sun, Z. P. et al. Hierarchically Structured $\mathrm{MnO}_{2}$ Nanowires Supported on Hollow Ni Dendrites for High-performance Supercapacitors. Nanoscale 5, 4379-4387 (2013).

21. Pang, S. C. \& Anderson, M. A. Novel Electrode Materials for Electrochemical Capacitors: Part II. Material Characterization of Sol-gel-derived and Electrodeposited Manganese Dioxide Thin Films. J. Mater. Res. 15, 2096-2106 (2000).

22. Yan, J., Khoo, E., Sumboja, A. \& Lee, P. S. Facile Coating of Manganese Oxide on Tin Oxide Nanowires with High-Performance Capacitive Behavior. ACS Nano 4, 4247-4255 (2010).

23. Zhang, H. et al. Growth of Manganese Oxide Nanoflowers on Vertically-Aligned Carbon Nanotube Arrays for High-Rate Electrochemical Capacitive Energy Storage. Nano. Lett. 8, 2664-2668 (2008).

24. Wang, H. L., Casalongue, H. S., Liang, Y. Y. \& Dai, H. J. Ni(OH $)_{2}$ Nanoplates Grown on Graphene as Advanced Electrochemical Pseudocapacitor Materials. J. Am. Chem. Soc. 132, 7472-7477 (2010)

25. Hou, Y., Cheng, Y. W., Hobson, T. \& Liu, J. Design and Synthesis of Hierarchical $\mathrm{MnO}_{2}$ Nanospheres/Carbon Nanotubes/Conducting Polymer Ternary Composite for High Performance Electrochemical Electrodes. Nano Lett. 10 2727-2733 (2010).

26. Bao, L. H., Zang, J. F. \& Li, X. D. Flexible $\mathrm{Zn}_{2} \mathrm{SnO}_{4} / \mathrm{MnO}_{2}$ Core/Shell NanocableCarbon Microfiber Hybrid Composites for High-Performance Supercapacitor Electrodes. Nano Lett. 11, 1215-1220 (2011).

27. Lu, X. H. et al. $\mathrm{WO}_{3-\mathrm{x}} @ \mathrm{Au} @ \mathrm{MnO}_{2}$ Core-Shell Nanowires on Carbon Fabric for High-Performance Flexible Supercapacitors. Adv. Mater. 24, 938-944 (2012).

28. He, Y. B. et al. Single-crystal ZnO Nanorod/Amorphous and Nanoporous Metal Oxide Shell Composites: Controllable Electrochemical Synthesis and Enhanced Supercapacitor Performances. Energy Environ. Sci. 4, 1288-1292 (2011).

29. Liu, J. P. et al. $\mathrm{Co}_{3} \mathrm{O}_{4}$ Nanowire@ $\mathrm{MnO}_{2}$ Ultrathin Nanosheet Core/Shell Arrays: A New Class of High-Performance Pseudocapacitive Materials. Adv. Mater. 23, 2076-2081 (2011)

30. Jiang, J. et al. General Synthesis of Large-Scale Arrays of One-Dimensional Nanostructured $\mathrm{Co}_{3} \mathrm{O}_{4}$ Directly on Heterogeneous Substrates. Cryst. Growth Des. 10, 70-75 (2010)

31. Lee, S. W. et al. Carbon Nanotube/Manganese Oxide Ultrathin Film Electrodes for Electrochemical Capacitors. ACS Nano 4, 3889-3896 (2010).

32. Liu, R. \& Lee, S. B. $\mathrm{MnO}_{2} /$ Poly (3, 4-ethylenedioxythiophene) Coaxial Nanowires by One Step Coelectrodeposition for Electrochemical Energy Storage. J. Am. Chem. Soc. 130, 2942-2943 (2008).

33. Sui, N., Duan, Y. Z., Jiao, X. L. \& Chen, D. R. Large-Scale Preparation and Catalytic Properties of One-Dimensional $\alpha / \beta-\mathrm{MnO}_{2}$ Nanostructures. J. Phys. Chem. C 113, 8560-8565 (2009).

34. Reddy, A. L. M., Shaijumon, M. M., Gowda, S. R. \& Ajayan, P. M. Coaxial MnO ${ }_{2} /$ Carbon Nanotube Array Electrodes for High-Performance Lithium Batteries. Nano Lett. 9, 1002-1006 (2009).

35. Yan, N. et al. $\mathrm{Co}_{3} \mathrm{O}_{4}$ Nanocages for High-Performance Anode Material in Lithium-Ion Batteries. J. Phys. Chem. C 116, 7227-7235 (2012).

36. Li, L., Li, Y., Gao, S. Y. \& Koshizaki, N. Ordered $\mathrm{Co}_{3} \mathrm{O}_{4}$ Hierarchical Nanorod Arrays: Tunable Superhydrophilicity without UV Irradiation and Transition to Superhydrophobicity. J. Mater. Chem. 19, 8366-8371 (2009).

37. Huang, H. et al. Nanocrystal-Constructed Mesoporous Single-Crystalline $\mathrm{Co}_{3} \mathrm{O}_{4}$ Nanobelts with Superior Rate Capability for Advanced lithium-Ion Batteries. ACS Appl. Mater. Interfaces 4, 5974-5980 (2012).

38. Wei, W. F., Cui, X. W., Chen, W. X. \& Ivey, D. G. Phase-Controlled Synthesis of $\mathrm{MnO}_{2}$ Nanocrystals by Anodic Electrodeposition: Implications for High-Rate Capability Electrochemical Supercapacitors. J. Phys. Chem. C 112, 15075-15083 (2008).

39. Xia, H. et al. $\mathrm{MnO}_{2}$ Nanotube and Nanowire Arrays by Electrochemical Deposition for Supercapacitors. J. Power Sources 195, 4410-4413 (2010).

40. Wang, F. C. et al. Effect of Pt Loading Order on Photocatalytic Activity of Pt/TiO Nanofiber in Generation of $\mathrm{H}_{2}$ from Neat Ethanol. J. Phys. Chem. C 113, 13832-13840 (2009).

41. Li, Y. M., Tang, L. H. \& Li, J. H. Preparation and Electrochemical Performance for Mrthanol Oxidation of Pt/Graphene Nanocomposites. Electrochem. Commun. 11, 846-849 (2009). 
42. Jiang, L. H. et al. Structure and Chemical Composition of Supported Pt-Sn Electrocatalysts for Ethanol Oxidation. Electrochim. Acta 50, 5384-5389 (2005).

43. Xia, H., Xiao, W., Lai, M. O. \& Lu, L. Facile Synthesis of Novel Nanostructured $\mathrm{MnO}_{2}$ Thin Films and Their Application in Supercapacitors. Nanoscale Res. Lett. 4, 1035-1040 (2009).

44. Yu, G. H. et al. Enhancing the supercapacitor performance of graphene/ $\mathrm{MnO}_{2}$ nanostructured electrodes by conductive wrapping. Nano. Lett. 11, 4438-4442 (2011)

45. Jiang, H. et al. Ultrafine Manganese Dioxide Nanowire Network for HighPerformance Supercapacitor. Chem. Commun. 47, 1264-1266 (2011).

46. Zhi, M. J. et al. Nanostructured carbon-metal oxide composite electrodes for supercapacitors: a review. Nanoscale 5, 72-88 (2013).

47. Kim, K. et al. High-frequency characterization of contact resistance and conductivity of platinum nanowires. IEEE Trans. Microwave Theo. Tech. 59, 2647-2654 (2011).

48. Jiang, J., Li, Y. Y., Liu, J. P. \& Huang, X. T. Building One-dimensional Oxide Nanostructure Arrays on Conductive Metal Substrates for Lithium-Ion Battery Anodes. Nanoscale 3, 45-58 (2011).

49. Era, A., Takehara, Z. \& Yoshizawa, S. Discharge Mechanism of the Manganese Dioxide Electrode. Electrochim. Acta 12, 1199-1212 (1967).

50. Guan, C. et al. Hybrid Structure of Cobalt Monoxide Nanowire @ Nickel Hydroxidenitrate Nanoflake Aligned on Nickel Foam for High-Rate Supercapacitor. Energy Environ. Sci. 4, 4496-4499 (2011).

51. Xia, H., Lai, M. O. \& Lu, L. Nanostructured Manganese Oxide Thin Films as Electrode Material for Supercapacitors. JOM 1, 54-59 (2011).

\section{Acknowledgments}

This work was supported by National Natural Science Foundation of China (No. 51102134 and 11134004), Natural Science Foundation of Jiangsu Province (No. BK20131349 and No. BK2011709), China Postdoctoral Science Foundation (No. 2013M530258), and Jiangsu Planned Projects for Postdoctoral Research Funds (No. 1202001B).

\section{Author contributions}

H.X., D.Z. and J.X. designed project, carried out data analyses and co-wrote the manuscript. Z.L. and Y.Y. performed the materials characterization. X.S. and G.Y. prepared figures 8-10.

\section{Additional information}

Supplementary information accompanies this paper at http://www.nature.com/ scientificreports

Competing financial interests: The authors declare no competing financial interests. How to cite this article: Xia, H. et al. Hierarchically Structured $\mathrm{Co}_{3} \mathrm{O}_{4} @ \mathrm{Pt} @ \mathrm{MnO}_{2}$ Nanowire Arrays for High-Performance Supercapacitors. Sci. Rep. 3, 2978; DOI:10.1038 srep02978 (2013).

(c) (i) (s) $(-)$ This work is licensed under a Creative Commons AttributionNonCommercial-NoDerivs 3.0 Unported license. To view a copy of this license, visit http://creativecommons.org/licenses/by-nc-nd/3.0 